\section{Ks. Dariusz Zagórski}

Uniwersytet Mikołaja Kopernika w Toruniu ecce@op.pl

ORCID: 000-0002-7674-6381

DOI: http://dx.doi.org/10.12775/BPTh.2020.020
Biblica

et

Patristica

Thoruniensia

13 (2020) 4: 451-463

ISSN (print) $1689-5150$

ISSN (online) 2450-7059

\title{
Człowiek w Expositio Evangelii secundum Lucam św. Ambrożego z Mediolanu
}

\section{Man in Expositio Evangelii secundum Lucam by St. Ambrose of Milan}

\begin{abstract}
Streszczenie. Nadrzędnym celem wykładu Ambrożego jest wskazanie odbiorcy właściwych środków do osiągnięcia podstawowego celu - zbawienia. Biskup Mediolanu, uświadamiając wiernym ich obecną kondycję, dokłada wszelkich starań, by ułatwić im postęp na drodze wewnętrznego rozwoju. Czyni to piętnując grzechy, przestrzegając przed działaniem szatana, ale przede wszystkim wykorzystuje każdą sposobność, aby z tekstu ewangelicznego wyciągnąć praktyczne wnioski dla dobrego życia chrześcijańskiego, to jest takiego, które po odrzuceniu grzechu, dążyłoby do głębokiego poznania Boga i prawdziwego rozmiłowania się w Nim.
\end{abstract}

Abstract. The teaching of St. Ambrose on human nature, which has fallen as a result of original sin, is closely based on the message contained in the Holy Scripture. In making the faithful aware of the current human condition, the bishop of Milan does his utmost to facilitate their progress in internal development. He takes every opportunity to draw practical conclusions for the good Christian life of the faithful, who, by renouncing sin, would strive for a profound cognizance of God and for developing a true love for Him.

Słowa klucze: teologia patrystyczna; święty Ambroży; człowiek; grzech pierworodny; świętość.

Keywords: Patristic theology; saint Ambrose; man; original sin; sanctity.

Najbardziej znanym i cenionym dziełem egzegetycznym św. Ambrożego jest Wykład Ewangelii według św. Łukasza. Powstało ono jako owoc kaznodziejskiej działalności biskupa Mediolanu i pomimo gruntownej redakcji tekstu, nadają- 
cej mu kształt systematycznego komentarza biblijnego, zachowało znamiona żywej mowy ${ }^{1}$. Homiletyczny charakter przekazu nadał dziełu etyczną użyteczność, dzięki czemu zawarte w nim ponadczasowe wskazówki również dzisiaj poruszają odbiorcę i skłaniają do poszukiwania doskonałości życia.

Według Ambrożego, dążenie do świętości, było podstawowym celem ludzkiej egzystencji, do którego człowiek został wezwany przez samego Boga. By jednak osiągnąć ów duchowy postęp i nie zatrzymać się w drodze ku zbawieniu, pasterz wielokrotnie w swym nauczaniu objaśniał wiernym zagadnienia związane z kondycją natury ludzkiej. Czynił to odwołując się do genealogii człowieka oraz ukazując skutki grzechu pierworodnego w świetle zbawczego dzieła Jezusa Chrystusa.

Mądrość, tkwiąca w wykładzie Ambrożego, miała być zachętą do świadomego wyboru drogi chrześcijańskiego doskonalenia. W swoim dziele biskup zalecał: „by nie przyjmowano nauki w sposób bezmyślny, tylko z posłuszeństwa, łatwowierności, czy też leniwej bezmyślności”2, lecz by badano wszystko i dokładnie doszukiwano się prawdy ${ }^{3}$.

\section{Stworzenie człowieka}

Stworzenie świata w nauczaniu Ambrożego jest pretekstem do ukazania potęgi Boga. Biskup Mediolanu akcentuje Jego moc, wszechobecność i wieczność. Podkreślona zostaje również jedność działania Osób Bożych w Trójcy Świętej. By podważyć stanowisko Ariusza, Ambroży wskazuje na równość Ojca i Syna we wszystkim ${ }^{4}$, również $\mathrm{w}$ akcie powoływania do istnienia poszczególnych bytów ${ }^{5}$.

1 A. Bogucki, Wstęp, w: Św. Ambroży, Wykład Ewangelii, s. 11.

2 J. Pałucki, Święty Ambroży jako duszpasterz, s. 122.

3 Ambrosius, Expositio Evangelii secundum Lucam 7, 189, SAEMO 12, s. 238; Św. Ambroży, Wykład Ewangelii według św. Łukasza, tłum. W. Szołdrski, PSP 16, Warszawa 1977 (dalej cytuję: PSP 16), s. 328.

4 F. Szabó, Le Christ Créateur chez saint Ambroise, Roma 1968, s. 45. Zob. także: D. Zagórski, Chrystus-Bóg, s. 71-78.

5 Ambrosius, Expositio Evangelii secundum Lucam 2, 12, SAEMO 11, s. 156; PSP 16, s. 54. Zob. także: Ambrosius, Expositio Evangelii secundum Lucam 1, 7, SAEMO 11, s. 100-102; PSP 16, s. 26-27: „W dziełach Ojca widzi się Jezusa, w czynach Syna widzi się i Ojca. Widział Jezusa, kto widział ową tajemnicę w Galilei, to jest przemianę wody w wino (J 2, 9-11). Tylko Pan świata może zmienić naturę danej rzeczy. Widzę Jezusa, gdy czytam, iż błotem pomazał oczy niewidomego i wzrok mu przywrócił $(J$ 9, 6). Tego znowu poznaję, kto z błota uczynił człowieka i dał mu ducha życia i wlał weń światło oczu (Rdz 2,7)”. 
Autor dzieła, odnosząc się do przekazu Księgi Rodzaju', podkreśla w akcie stwórczym wyjątkowość powołania człowieka. Podczas bowiem, gdy wszystkie inne elementy świata miały zostać utworzone z mocy Bożego rozkazu, w kreacji ludzkiej istoty widoczne było szczególne „zaangażowanie” Stwórcy. W Expositio Evangelii secundum Lucam czytamy:

Pouczył mnie też Mojżesz, iż tylko Bóg świat stworzył: „Na początku Bóg stworzył niebo i ziemię" (Rdz 1,1). Pouczył też, iż stworzenie człowieka jest czynem Boga i nie darmo podał: „Utworzył Bóg człowieka z mułu ziemi i tchnął w oblicze jego dech żywota" (Rdz 2,7) abyś poznał, że Bóg stwarzając człowieka, działał w sposób niejako fizyczny. Pouczył też, że Bóg stworzył i niewiastę: „Zesłał Bóg sen na Adama i zasnął i wyjął jedno żebro z boku jego i napełnił ciałem miejsce jego. I zbudował Pan Bóg z żebra, które wyjął z Adama, niewiastę" (Rdz 2,23). Nie na próżno [stwierdza Ambroży - D.Z.] przy stworzeniu Adama i Ewy przedstawił Mojżesz Boga, jakby pracującego rękami. Bóg kazał, aby stał się świat i stał się. Pismo jednym słowem podaje stworzenie świata. Skoro jednak szło o człowieka, to starał się prorok przedstawić ci Boga, jakby pracującego rękami ${ }^{7}$.

Osobliwość bytu ludzkiego Biskup Mediolanu dostrzegał nie tylko w powołaniu go do życia. Tym, co czyniło człowieka wyjątkowym, miała być zdolność do podejmowania wolnych decyzji, w oparciu o wolną wolę ${ }^{8}$. Stąd istotą antropologii Ambrożego jest zwrócenie uwagi na dwupodział występujący w człowieku, polegający na złożeniu bytu ludzkiego z ciała i duszy ${ }^{9}$. Doktor Kościoła podkreślał w tej kwestii kierowniczą rolę elementu duchowego, któremu panowanie nad impulsami ciała zlecone zostało przez samego Stwórcę:

Albowiem mądrość jest pokarmem ducha, wyśmienitym pożywieniem bardzo słodkim, które nie obciąża członków, nie sromoci natury, ale ją zdobi. Wówczas bagno żądz zamienia się w świątynię Boga i zbiorowisko występków zaczyna być świętym przybytkiem cnót. Oczywiście wtedy się to dzieje, gdy ciało odzyskuje swą naturę, rozpoznaje żywicielkę swej mocy i wyzbywszy się zuchwałego uporu, poddaje się duszy, która nim kieruje. Takim było, gdy na miejsce swego pobytu

6 Do egzegezy Księgi Rodzaju Ambroży powracał w swych dziełach wielokrotnie. Poświęcił jej kilka osobnych pism. Zob. D. Zagórski, Oblicza Chrystusa, s. 13-14. Zob. także: A. Bogucki, Wstęp, w: Św. Ambroży, Hexaemeron, s. 16.

7 Ambrosius, Expositio Evangelii secundum Lucam 2, 85, SAEMO 11, s. 224; PSP 16, s. 88 .

8 Ambrosius, Expositio Evangelii secundum Lucam 6, 77, SAEMO 12, s. 66; PSP 16, s. $238-239$.

9 Zob. D. Zagórski, „Perfectio hominis”, s. 140: „Tema assai importante dell’antropologia [di Ambrogio] è la bipartizione dell'uomo in corpus e anima". 
raj otrzymało, zanim dotknięte jadem zgubnego węża, świętokradzki głód poczuło i w swej żądzy nasycenia się nie pamiętało o boskich przykazaniach, jakie są w świadomości duszy ${ }^{10}$.

Podobnie jak w innych swych dziełach Ambroży w Wykładzie Ewangelii według św. Łukasza podkreślał znaczenie części rozumnej duszy, to jest umysłu (mens). Jemu to przypiswał dominującą rolę nie tylko nad ciałem, lecz także nad nierozumnymi częściami duszy człowieka ${ }^{11}$.

Cechą charakterystyczną wykładu Biskupa jest rygorystyczne trzymanie się Pisma Świętego i unikanie zbędnych dywagacji. Naukę o stworzeniu świata, w tym człowieka, stara się wyłożyć wiernym zgodnie z przekazem biblijnym. Będąc wyczulonym na rzeczywiste znaczenie świętego tekstu, dba o to, by „poznawanie dzieła dokonanego przez Boga” nie opierało się na ludzkich domniemaniach. Potrafi jednocześnie z pokorą przyznać się przed adresatami: „iż więcej nie wie, ponad to, co czyta” ${ }^{12}$. Wszystkich spragnionych odkrywania prawdy zachęca do poszukiwania głębszego, duchowego znaczenia biblijnego tekstu. Wskazuje, iż pomocą w tym względzie są inne księgi Biblii, których Autorzy, natchnieni „Duchem Bożym”, wyjaśniają przekaz wcześniej zakryty i niezrozumiały ${ }^{13}$.

\section{Upadek człowieka}

Ambroży, przywołując obraz raju, konsekwentnie akcentuje wyjątkowość człowieka w całym dziele stworzenia. Opis szczęścia pierwszych rodziców żyjących w bliskości Boga, dobitnie kontrastuje z tragizmem sytuacji po grzechu, którego dopuścili się Adam i Ewa:

10 Ambrosius, Expositio Evangelii secundum Lucam 7, 142, SAEMO 12, s. 202; PSP 16, s. 308. Por. Ambrosius, De Iacob et vita beata I 1, 4, SAEMO 3, s. 234-235.

11 Ambrosius, Expositio Evangelii secundum Lucam 8, 50, SAEMO 12, s. 322-324; PSP 16, s. 371. Zob. D. Zagórski, „Perfectio hominis”, s. 141: „Alla mens dell’uomo (che è la parte razionale dell'anima - il centro della razionalità), «in quanto regina e signora dei sensus e dei motus dell'uomo, spetta il dominio sopra le parti inferiori dell'anima (parte irrazionale di essa) e del corpo»". Zob. E. Dassmann, La sobria ebbrezza, s. 32-33.

12 Ambrosius, Expositio Evangelii secundum Lucam 2, 86, SAEMO 11, s. 224; PSP 16, s. 88 .

13 Ambrosius, Expositio Evangelii secundum Lucam 2, 86, SAEMO 11, s. 224; PSP 16, s. 89 . 
Pierwszy [Adam] był stworzony na obraz Boga, druga [Ewa] zażywała mocy swego męża, póki silniejszemu od niej była poddana. Czynność obojga była miłą Bogu i umieszczeni w raju, niebiańskim pokarmem utrzymywali się przy życiu. Później zaś, gdy ciało coś innego im poradziło i zaczęło nie uwzględniać Bożego prawa, zostali z raju wygnani i słusznie wpadli w to poniżej będące miejsce grzechu ${ }^{14}$.

Przedstawiając realia człowieka po upadku, Biskup Mediolanu podkreśla skrępowanie ducha ludzkiego, który związany został i zniewolony ${ }^{15}$ poprzez zasadzki szatana ${ }^{16}$. Rola duszy, mającej panować nad ciałem, została zachwiana, a dokonało się to wszystko w związku z próżnością, która wzmogła w stworzeniu pragnienie upodobnienia się do Boga:

Zwiodło bowiem Adama pragnienie pokarmu; udał się lekkomyślnie tam, gdzie było owo zakazane drzewo, dopuścił się zuchwale występku próżności - chciał upodobnić się do Boga. [...] Nie pokarm zachwiał Ewą, nie zwiodło jej, iż zapomniała o nakazach, lecz załamała ją zarozumiałość, z jaka pragnęła otrzymać obiecaną zaszczytną godność ${ }^{17}$.

Ambroży uświadamia odbiorcy, że grzech pierworodny odcisnął swe znamię na wszystkich ludziach ${ }^{18}$. Sytuację człowieka od momentu sprzeniewierzenia się Stwórcy porównuje do ciężkiej, niedającej się uleczyć choroby, podczas której duch ludzki „związany i trawiony ciała gorączką wraz z nim choruje”19. Ową gorączką doskwierającą człowiekowi stają się żądze zmysłowe, które są narzędziem niszczącym nie tylko ciało, ale także całego człowieka:

14 Ambrosius, Expositio Evangelii secundum Lucam 4, 66, SAEMO 11, s. 352; PSP 16, s. 157.

15 W De Iacob et vita beata Ambroży mówi wręcz o „niewolniczym dziedzictwie”, które dotknąć miało cały rodzaj ludzki po grzechu pierworodnym. Biskup Mediolanu Adama i Ewę obarcza winą za to, że zaprzedali człowieka grzechowi, który zapanował nad nim jak pan nad swym niewolnikiem (zob. D. Zagórski, „Perfectio hominis”, s. 141).

16 Ambrosius, Expositio Evangelii secundum Lucam 4, 62, SAEMO 11, s. 348; PSP 16, s. 156: „[...] Duch skrępowany [został] wężowymi zasadzkami. Duszy bowiem nigdy ciało nie zwycięży, jeśli jej pierwej szatan nie skusi. Dusza bowiem ciało porusza, ożywia i nim rządzi. Jakże może ona dać się porwać jego ponętom, jeśli jej przedtem nie skrępują więzy jakiejś wyższej władzy?”.

17 Ambrosius, Expositio Evangelii secundum Lucam 4, 33-34, SAEMO 11, s. 324-326; PSP 16, s. 143. Zob. także Ambrosius, Expositio Evangelii secundum Lucam 4, 62, SAEMO 11, s. 348; PSP 16, s. 156: „Ewa nie czuła głodu, zanim jej swą przewrotnością wąż nie skusił”.

18 Ambrosius, Expositio Evangelii secundum Lucam 4, 67, SAEMO 11, s. 352; PSP 16, s. 158.

19 Ibidem. Zob. E. Dassmann, La sobria ebbrezza, s. 34-35. 
Naszą bowiem gorączką jest żądza zmysłowa. Żądze jak ogień działają. [...] Naszą gorączką jest rozpusta, naszą gorączką jest gniew. Te choć są występkami ciała, przenikają jednak kości, oddziałują na umysł, na ducha, na uczucia. Szatan najpierw podstępnie ciało kusi. Sidłami węża; dobre pola, szaty, klejnoty, godności, wysokie stanowiska, smakowite uczty, piękność nierządnicy to sidła szatana; są jakby ponętną namową skierowaną do ciała, które niejako z niewieścią zmiennością szybko im ulega, a i ducha także z jego wyżyn strąca. Nie pierwej bowiem, niż oko ciała, pożąda duch pięknej niewiasty. Wreszcie nie pokochasz tego, czego nie widzisz. Gdy ciało żądzę rozpali znika stałość czującego z nim wspólnie ducha. Umysł pod wpływem towarzyszącego mu uczucia miłości słabnie - „dwoje są bowiem w jednym ciele" (Rdz 2,24; Mt 19,5) i ulegając pokusie szatana, pobudzony przez ciało, dopuszcza się występku, następuje śmierć (duchowa) ${ }^{20}$.

Grzech pierworodny - jak naucza Biskup Mediolanu - stał się przyczyną słabości kondycji ludzkiej i wewnętrznego rozdarcia człowieka. Ta sama słabość znalazła odbicie w całym świecie, który odtąd nosi w sobie skutki niewoli zepsucia $^{21}$.

\section{Odkupienie człowieka}

Ambroży przestrzega, że gdy człowiek zejdzie z drogi, na której został postawiony przez Stwórcę $\mathrm{w}$ raju ${ }^{22}$, to ponowne na nią wstąpienie jest możliwe jedynie ze wsparciem od Boga. Pomoc nie przyjdzie z żadnej innej strony, nawet od potężnych duchów, jakimi są aniołowie. Jedynym zdolnym wyswobodzić ludzkość z sytuacji, w której się znalazła jest Jezus Chrystus, Syn Boży. To On ma moc rozerwać wszystkie sidła przygotowane i zastawione przez szatana:

Jakiego więc (Bóg) miał nam udzielić wodza przeciw tylu pokusom świata, przeciw tak wielu zasadzkom szatana, skoro wiedział, iż najpierw mamy walczyć „Z ciałem i krwią, a następnie z rządcami świata tych ciemności, przeciw złym duchom w przestworzach niebiańskich"? (Ef 6,11-12). A czyż Anioła przeciwstawi? Ale i ten upadł i legiony aniołów nic by mu nie pomogły. Czy Serafina miałby wy-

20 Ambrosius, Expositio Evangelii secundum Lucam 4, 63, SAEMO 11, s. 348-350; PSP 16, s. 156.

21 Ambrosius, De Iacob et vita beata I 6, 24, SAEMO 3, s. 255: „Quid illud quod labor tibi communis cum omni est creatura, quia propter te mundus ipse servitutem tolerat corruptionis?"

22 Ambrosius, Expositio Evangelii secundum Lucam 4, 8, SAEMO 11, s. 306; PSP 16, s. 132. 
słać? Ale i ten zstąpił na ziemię do ludu mającego nieczyste usta, ale zdołał tylko oczyścić usta proroka kamykiem, którym ich dotknął (Iz 6,5-6). Innego wodza było potrzeba, abyśmy wszyscy szli za nim. Któż jednak jest tak wielkim wodzem, aby pomógł wszystkim, jeśli nie Ten, który jest ponad wszystkimi? Któż mnie ponad świat wzniesie, jeśli nie Ten, który większy jest od świata? (J 3,31) Któż tak wielkim jest wodzem, który by zdołał mężczyznę i niewiastę, Żyda i Greka, barbarzyńcę i Scytę, niewolnika i wolnego rządzić jednym skinieniem, jeśli nie jedynie Chrystus, który jest wszystkim we wszystkim? $(\operatorname{Kol} 3,11)^{23}$

Dla Ambrożego Chrystus jest lekarzem mogącym uleczyć skaleczonego ducha ludzkiego i przywrócić człowiekowi życie ${ }^{24}$. W swoim dziele podkreśla, że znaki uzdrowień człowieka, jakie miały miejsce, gdy Pan przebywał pośród ludzi, jednoznacznie wskazują na Jego bóstwo - jest On zatem nie tylko uzdrowicielem natury ludzkiej, ale także jej odnowicielem ${ }^{25}$.

Biskup Mediolanu ściśle łączy zstąpienie Syna Bożego na Ziemię z aktem zbawczym. W Expositio Evangelii secundum Lucam ukazane jest ono jako zatroskanie Stwórcy świata o swoje dzieło ${ }^{26}$. Ambroży podkreśla dobrowolność tego aktu ze strony Zbawiciela, a także wskazuje na wolę ratowania przez Pana jak największej liczby istnień ludzkich ${ }^{27}$. Dramatem wielu stało się jednak to, że

23 Ambrosius, Expositio Evangelii secundum Lucam 4, 9, SAEMO 11, s. 306; PSP 16, s. 133.

24 Ambrosius, Expositio Evangelii secundum Lucam 4, 67, SAEMO 11, s. 352; PSP 16, s. 158: „Lecz nasz duch związany, przybity, trawiony ciała gorączką wraz z nim choruje. Trzeba szukać lekarza, lecz któż jest tak wielkim lekarzem, kto skaleczonego ducha potrafiłby uleczyć? Któryż człowiek zdoła innym dopomóc, skoro sobie pomóc nie może? Czy potrafi innym życie przywrócić, jeśli sam śmierci nie mógł uniknąć?"

25 Ambrosius, Expositio Evangelii secundum Lucam 10, 70-71, SAEMO 12, s. 446; PSP 16, s. 431: „Zrozum, jeśli zdołasz, jak się to dzieje, iż za dotknięciem prawicy Zbawiciela ból znika i rany, nie leczone środkami leczniczymi, przez samo dotknięcie są uzdrowione. Mół ziemi uznaje swego Twórcę ( $\mathrm{Rdz} 2,7)$ i twórczej ręce swego Pana ulega ciało. Stwórca, jak chce, odnawia swe dzieło. Jak gdzie indziej tu przywraca wzrok ślepemu, namaściwszy oko błotem (J 9, 6), jakby ono odzyskało swą własność przyrodzoną. Mógł rozkazać, ale wolał działać, abyśmy poznali, iż On z mułu ziemi utworzył nasze członki, przystosowane do wypełniania różnych obowiązków i ducha ożywił, udzielając mu mocy. (...) Oni sprawiedliwemu śmierć zadali, Ten zaś uleczył prześladowców rany”.

26 Ambrosius, Expositio Evangelii secundum Lucam 10, 96, SAEMO 12, s. 462; PSP 16, s. 439: „Przybył bowiem, aby świat był zbawiony przez Niego (J 3, 17), w którym Twórca ma swoje dzieło i doń prawo. Przybył więć, aby zachować dla szczęścia wiecznego tych, którzy przez chrzest byli pogrzebani w Chrystusie i z Nim współumarli (Rz 6, 4, 8; Kol 2, 12)".

27 Ambrosius, Expositio Evangelii secundum Lucam 4, 56, SAEMO 11, s. 342-344; PSP 16, s. 153-154: „Zrozum zarazem, iż nie z konieczności to uczynił, lecz dobrowolnie przyjął cielesne cierpienia; Żydzi Go nie pojmali, lecz sam im się oddał. Albowiem, kiedy chce, daje 
nie byli w stanie przyjąć daru, jaki zaoferował im Wcielony Bóg. Odrzucili go tracąc w ten sposób przyniesione przez Syna zbawienie:

Świętokradztwa Żydów, jakie Pan na długo przedtem przepowiedział przez proroka, a i słowami psalmu oświadczył, co ucierpi w swym ciele: „Oddawali mi złem za dobre" (Ps 34,12), teraz poucza w Ewangelii, iż się to spełniło. Albowiem gdy On ludziom obficie dobrodziejstw udzielił, oni obrzucali Go zniewagami. Nic dziwnego, iż ci utracili zbawienie, którzy ze swoich granic wyrzucili Zbawiciela (Mt 8,34). A takie jest postępowanie Pana: Ten, który swoim przykładem uczył swych apostołów, aby dla wszystkich wszystkim się stali (1 Kor 9,22), chcących nie odrzuca; tych, którzy nie chcą, nie przymusza; nie opiera się tym, którzy Go odtrącają, a nie brak Go tym, którzy Go prosząa ${ }^{28}$.

Celem Ambrożego jest uświadomienie znaczenia ofiary Chrystusa i wskazanie na cenę jaką musiał zapłacić Zbawiciel, by uwolnić ludzkość od śmierci wiecznej. Chcąc obrazowo ukazać odbiorcom, jak wielka była wartość dzieła dokonanego przez Pana, w opozycji do niego stawia poczynania przeciwnika człowieka - Szatana. On to, zniewalając uległych mu grzeszników „sprzedaje ich za niską cenę", jak nic nie znaczący towar; tylko Bóg nabywa człowieka za wysoką cenę (1 Kor 6,20), oszacowuje nie wartością pieniądza, lecz płaci swą najdroższą, pochodzącą z nieskazitelnego ciała, krwią ${ }^{29}$.

się schwytać, kiedy chce, zostaje (na krzyżu) zawieszony; gdy zechce zatrzymany być nie może. I tu wszedł na szczyt góry, z której strącić Go chciano, a oto, gdy umysł rozgniewanych się zmienił lub zdumiał, przeszedł pośród nich i zstąił; nie nadeszła jeszcze bowiem godzina Jego męki. Chciał jeszcze Żydów raczej uzdrowić, niż zgubić. A oni widząc bezskuteczność swego gniewu, woleli raczej odstąpić od tego, czego wykonac nie mogli. Widzisz więc i w tym, co uczynił, objaw Jego Bóstwa, a i to, że Go schwytano, stało się z Jego woli. Jakże bowiem niewielu mogłoby Go zatrzymać, skoro cały lud zatrzymać Go nie mógł? Nie chciał jednak, aby wielu dopuściło się świętokradztwa; hańbę przybicia Go do krzyża chciał odwrócić na twórców tego czynu. Niewielu Go przybiło, lecz umarł za świat cały”.

28 Ambrosius, Expositio Evangelii secundum Lucam 4, 55, SAEMO 11, s. 342; PSP 16, s. 153.

29 Ambrosius, Expositio Evangelii secundum Lucam 7, 117, SAEMO 12, s. 178; PSP 16, s. 296: „Przeciwnik (szatan) niejako swych niewolników sprzedaje za niską cenę. Natomiast Pan, który stworzył swe sługi na obraz i podobieństwo swoje, oceniając należycie swe dzieło, za cennych ich uważał i za wielka cenę nas odkupił, jak to święty Apostoł powiedział: «Albowiem nabyci byliście za wysoką cenę» (1 Kor 6,20). I prawdziwie «wysoką», ocenia się ją nie pieniędzmi, lecz krwią, ponieważ Chrystus umarł za nas i cenną krwią swoją nas odkupił, jak o tym też mówi św. Piotr w swym liście, pisząc do nas: «Nie skazitelnym złotem albo srebrem zostaliście wyzwoleni z nędznego sposobu życia waszych ojców, ale cenną krwią jakby niezmazanego i niepokalanego baranka Chrystusa Jezusa» (1 P 1, 18-19). I prawdzi- 


\section{Dążność człowieka do świętości}

Ambrozjański program doskonalenia chrześcijańskiego „jest uzależniony od wielu czynników, którymi są przede wszystkim cel oraz środki, jakimi dysponuje doskonalący się człowiek, a więc powrót do "prawdziwego obrazu Boga» w człowieku przez coraz to doskonalsze naśladowanie Chrystusa" ${ }^{30}$. Realizacja tego zamysłu zależna jest od wysiłków chrześcijanina, który winien być złączony z mocą Zbawiciela na zasadzie posłuszeństwa wobec Niego, to jest przestrzegania zalecanych przez Pana norm, w postawie wewnętrznej ich akceptacji ${ }^{31}$.

W nauczaniu Biskupa Mediolanu wyróżnić można dwa zasadnicze etapy procesu dążenia ku świętości, są nimi nawrócenie i postęp w doskonaleniu:

Pilnie rozważ wszystko! Jak [Jezus - D.Z.] z apostołami wstępuje i do rzesz schodzi. Czyż rzesza mogła widzieć Chrystusa gdzie indziej, jeśli nie na równinie? Ta nie idzie (za Nim) na górę, nie wstępuje ku wyżynom. Dopiero wtedy, gdy zeszedł, znalazł chorych; na wyżynach bowiem chorych być nie może. A i Mateusz poucza (Mt 8,1), że na równinach chorzy byli uzdrawiani. Pierwej bowiem każdy musi wyzdrowieć, aby następnie, nabywając cnót, mógł wstąpić na górę. Toteż Pan na równinach uzdrawia, to jest od zaspokajania żądz powściąga, ślepotę (ducha) usuwa, zstępuje do naszych ran, aby niejako przestając z nami i oddając się nam całkowicie, uzdolnić nas do nabycia niebiańskiej natury ${ }^{32}$.

Głębię nauki Ambrożego, odnoszącą się do zagadnienia nawrócenia człowieka, odnaleźć można w omawianym komentarzu przy okazji prowadzonej przez biskupa egzegezy trzech przypowieści ewangelicznych: o zagubionej owcy, o utraconej drachmie i o synu marnotrawnym. Pasterz świadomy ludzkich słabości, wskazuje wiernym środki zabezpieczające przeciw błędom i podkreśla, że miłosierny Bóg nigdy nie odmówił człowiekowi nadziei przebaczenia. Przeciwnie - jest zawsze gotowy udzielać wsparcia, by dokonać się mogło jego wewnętrzne uzdrowienie:

Toteż nie na darmo święty Łukasz podał ci trzy, jedna po drugiej przypowieści [...], abyśmy zachęceni potrójnym lekarstwem, nasze rany nim leczyli. Kim są owi:

wie «cenną» bo jest krwią niepokalanego ciała, bo jest krwią Syna Bożego, bo nie tylko od przekleństwa Zakonu (Ga 3, 18), lecz i z bezbożności śmierci wiecznej nas wykupił”.

30 J. Pałucki, Święty Ambroży jako duszpasterz, s. 120. Zob. D. Zagórski, Jezus Chrystus, s. 58 .

31 J. Pałucki, Święty Ambroży jako duszpasterz, s. 120.

32 Ambrosius, Expositio Evangelii secundum Lucam 5, 46, SAEMO 11, s. 398; PSP 16, s. $180-181$. 
Ojciec, pasterz, niewiasta [z przypowieści - D.Z.]? Czyż nie Bóg Ojciec, Chrystus, Kościół: Chrystus Cię niesie na swoim ciele, gdyż przyjął na siebie twe grzechy; Kościół cię szuka; Ojciec cię przyjął z powrotem. Jako pasterz cię niesie, jako matka cię szuka, jako ojciec przyodziewa. Najpierw miłosierdzie, następnie orędownictwo, na trzecim miejscu pojednanie. Każde z nich inne uzupełnia. Odkupiciel wspomaga, Kościół oręduje, Stwórca przebacza. Takie samo jest działanie miłosierdzia Bożego, lecz różna jest łaska stosowana według naszych zasług ${ }^{33}$.

W licznych dziełach Biskupa Mediolanu znajdziemy opis przebiegu aktu pokutnego, jako drogi powrotu człowieka do Boga ${ }^{34}$. Ważnym i jednocześnie poruszającym w tym akcie jest motyw „obmycia łzami”:

[Piotr] wolał bowiem sam siebie oskarżyć ze swego grzechu, aby się usprawiedliwić wyznaniem, niż powiększyć swą winę, nie chcąc się do niej przyznać, albowiem sprawiedliwy najpierw sam siebie oskarża (Prz 18,17) i dlatego płakał. Dlaczego płakał? Ponieważ wina do niego się wślizgnęła. Ja zwykłem płakać, gdy mi brak grzechu, to jest, jeśli się nie mszczę, jeśli nie otrzymuję tego, czego niegodziwie pożądam. Piotr bolał i płakał, bo zgrzeszył jak człowiek. Nie wiem, co mówił, ale wiem, iż płakał. Czytam o jego łzach, nie czytam, jak zadośćuczynił. Lecz to, czego nie da się obronić, można obmyć. Łzy obmywają winę, do której wstyd jest głosem się przyznać. Płacz zaradza winie i wstydowi ${ }^{35}$.

Charakterystyczną cechą omawianego komentarza jest optymizm, wyzwalający od strachu i niosący nadzieję na możliwość poprawy życia i jego ciągłego doskonalenia ${ }^{36}$. Wynika to z faktu, iż Ambroży jest bardziej moralistą niż

33 Ambrosius, Expositio Evangelii secundum Lucam 7, 207-208, SAEMO 12, s. 252-254; PSP 16, s. 336.

34 Przykładem precyzyjnego omówienia tego procesu jest ambrozjański Komentarz do Psalmu XXXII. Zob. D. Zagórski, Przebieg aktu pokutnego, s. 171-183.

35 Ambrosius, Expositio Evangelii secundum Lucam 10, 87-88, SAEMO 12, s. 456-458; PSP 16, s. 436-437. Zob. Ambrosius, Expositio Evangelii secundum Lucam 5, 92, SAEMO 11, s. 428; PSP 16, s. 197: „A chociaż grzech jest ciężki i sam łzami swej pokuty obmyć go nie możesz; to niech za ciebie błaga matka, Kościół, który jak matka wdowa, wstawia się niejako za swych jedynaków. Lituje się nad nimi, doznając niejako duchowego, naturalnego bólu, widząc, jak jej dzieciom z powodu ich ciężkich występków śmierć grozi”. Zob. M. Sołomieniuk, Motyw płaczu, s. 105-126; W. Kamczyk, Grzeszna kobieta, s. 183.

36 Ambrosius, Expositio Evangelii secundum Lucam 7, 212, SAEMO 12, s. 256-4258; PSP 16, s. 337: „Nie lękajmy się, iż dla uciech ziemskich zmarnowaliśmy dziedzictwo duchowej godności, jakie otrzymaliśmy, albowiem Ojciec dał Synowi skarb, jaki posiadał. Bogactwo wiary nigdy się nie wyczerpuje. Choćby wszystko dał, wszystko ma, a tego, co udzielił, nie utracił. Nie bój się, iż cię nie przyjmie, «nie weseli się bowiem Bóg ze zguby żywych» (Mdr 1, 13). Już spieszy naprzeciw ciebie, rzuci ci się na szyję. Pan bowiem pod- 
egzegetą, a jako moralista posiada trzeźwy osąd rzeczywistości. W wymaganiach kierowanych do odbiorców „unika krańcowości; nie jest ani bezdusznym rygorystą ani pobłażliwym konformistą. Poza tym wystrzega się zwykłej moralistom jednostronności, polegającej na zbytnim koncentrowaniu uwagi na negatywnych przejawach ludzkiego postępowania" ${ }^{37}$.

W swoim nauczaniu Ambroży podkreśla, że słabość natury ludzkiej nie jest czynnikiem usprawiedliwiającym brak duchowego postępu. Jego zdaniem chrześcijanin nie może tłumaczyć zaniechań na drodze wewnętrznego doskonalenia się wrodzoną ułomnością. Kwestię dążenia ku świętości Biskup Mediolanu przywołuje w interpretacji perykopy poświęconej zapowiedzi narodzin Jana Chrzciciela. Sprawiedliwość i wierność przykazaniom cechujące rodziców Proroka są dla Ambrożego pretekstem do krytyki poglądów, które odmawiają wyznawcom Chrystusa możliwości zerwania z grzechem i odrzucają naukę o Bożym wsparciu, czyli o łasce:

Jeśli jednak twierdzą [oni], że ten, kto dawny błąd naprawił i odmienił sposób swego życia, nie może powstrzymać się od grzechu, to na to twierdzenie zgodzić się nie mogę, albowiem czytamy: „Tak Pan umiłował Kościół [...] aby zgotować go sobie chwalebnym, nieskalanym, bez zmazy, bez czegokolwiek, lecz aby był święty i niepokalany" (Ef 5,27). Skoro bowiem Kościół został zebrany z pogan, to jest z grzeszników, to jakże może być nieskalanym, jeśli łaska Boża pierwej z win go nie obmyje, a następnie nie usposobi go do niegrzeszenia i od win nie powstrzyma? Nie był więc Kościół nieskalanym od początku. Dla ludzkiej natury jest to niemożliwe, lecz dzięki łasce Boga, mając uzdolnienie do niepopełniania grzechów, Kościół zdaje się być nieskalanym ${ }^{38}$.

To właśnie współdziałanie człowieka z łaską Bożą powoduje postęp chrześcijanina $\mathrm{w}$ cnocie i prowadzi go na szczyty świętości. Bóg pragnie wspierać dobre starania ludzkie, a człowiek winien dostrzec wyjątkowość udzielanej pomocy. Wszystko bowiem ma ostatecznie na celu uznanie wszechmocy Stwórcy

nosi upadłych (Ps 145, 8). Pocałuje cię, co jest oznaką serdeczności i miłości; każe, aby ci przyniesiono szaty, pierścień, sandały. Jeszcze się lękasz, iż będziesz odtrącony, a On ci przywraca twą godność, boisz się kary, On cię całuje; lękasz się wyrzutów, On rozkazuje przygotować ci ucztę".

37 A. Bogucki, Wstęp, w: Św. Ambroży, Wykład Ewangelii, s. 14.

38 Ambrosius, Expositio Evangelii secundum Lucam 1, 17, SAEMO 11, s. 112-114; PSP 16, s. 32 . 
i uświadomienie człowiekowi, że każdy jego czyn winien być podejmowany na chwałę Bożą

\section{Bibliografia}

\section{Teksty źródłowe:}

Ambrosius, De Iacob et vita beata $=$ Sancti Ambrosii Episcopi Mediolanensis Opera (= SAEMO), vol. 3; introduzione, traduzione, note e indici di R. Palla, Milano Roma 1982, s. 215-226 (introduzione e bibliografia), s. 228-333 (testo e traduzione).

Ambrosius, Expositio Evangelii secundum Lucam (Libri I-IV) = Sancti Ambrosii Episcopi Mediolanensis Opera (= SAEMO), vol. 11; introduzione, traduzione, note e indici di G. Coppa, Milano - Roma 1978.

Ambrosius, Expositio Evangelii secundum Lucam (Libri VI-X) = Sancti Ambrosii Episcopi Mediolanensis Opera (= SAEMO), vol. 12; introduzione, traduzione, note e indici di G. Coppa, Milano - Roma 1978.

Św. Ambroży, Wykład Ewangelii według św. Łukasza, tłum. W. Szołdrski, PSP 16, Warszawa 1977.

\section{Opracowania:}

Bogucki A., Wstęp, w: Św. Ambroży, Hexaemeron, tłum. W. Szołdrski, PSP 4, Warszawa 1969, s. 13-32.

Bogucki A., Wstęp, w: Św. Ambroży, Wykład Ewangelii według św. Łukasza, tłum. W. Szołdrski, PSP 16, Warszawa 1977, s. 9-15.

Dassmann E., La sobria ebbrezza dello spirito, Sacro Monte Varese 1975.

Kamczyk W., Grzeszna kobieta (Łk 7, 36-50) jako obraz Kościoła w nauczaniu św. Ambrożego, VoxP 37 (2017), t. 67, s. 177-195.

Pałucki J., Święty Ambroży jako duszpasterz w świetle ekshortacji pastoralnych, Lublin 1996.

Sołomieniuk M., Motyw płaczu w mowach żałobnych św. Ambrożego, TPatr 7 (2010), s. $105-126$.

Szabó F., Le Christ Créateur chez saint Ambroise, Roma 1968.

39 Ambrosius, Expositio Evangelii secundum Lucam 1, 31, SAEMO 11, s. 128; PSP 16, s. 39: „Jest wobec Pana wielkość duszy, wielkość cnoty; jest też małość duszy, i dzieciństwo cnoty. Toteż odmierzamy wiek duszy i ciała nie miarą czasu, lecz jakością cnoty. Tego nazywamy doskonałym, kto nie popełnił uchybień w młodości, kto będąc dojrzały duchowo młodzieńczą swawolę trzymał na wodzy”. Zob. Ambrosius, Expositio Evangelii secundum Lucam 2, 84, SAEMO 11, s. 222; PSP 16, s. 88. 
Zagórski D., Chrystus-Bóg w „Hexaemeronie” św. Ambrożego, „Studia Sandomierskie” 14 (2007), z. 1, s. 69-80.

Zagórski D., Jezus Chrystus w „Expositio Evangelii secundum Lucam” św. Ambrożego, „Teologia Patrystyczna” 7 (2010), s. 57-66.

Zagórski D., Ludzka natura Chrystusa w „Hexaemeronie” św. Ambrożego, „Kaliskie Studia Teologiczne” 5 (2006), s. 341-350.

Zagórski D., Oblicza Chrystusa w „Hexaemeronie” św. Ambrożego, Bydgoszcz 2007.

Zagórski D., „Perfectio hominis” nel „De Iacob et vita beata” di s. Ambrogio, VoxP 25 (2005), t. 48, s. 139-152.

Zagórski D., Przebieg aktu pokutnego na podstawie „Komentarza do Psalmu XXXVII” św. Ambrożego, RTK 53 (2006), z. 4, s. 171-183. 